\title{
The importance of dietary calcium consumption in two species of semi-terrestrial grapsoid crabs
}

\author{
Flavia P. Zanotto ${ }^{1}$, Felipe Pinheiro ${ }^{2} \&$ Marina G. e Sá ${ }^{2}$
} 1. Centro de Ciências Biológicas e da Saúde, Universidade Presbiteriana Mackenzie, Rua da Consolação 930, 01302-907 São Paulo, SP,
Brazil. (fzanotto@ mackenzie.br)
2. Departamento de Fisiologia, Instituto de Biociências, Universidade de São Paulo, Cidade Universitária, Rua do Matão, Travessa 14,
05508-900 São Paulo, SP, Brazil. (felipediver@ib.usp.br; marinagranado@gmail.com)

\begin{abstract}
Calcium $(\mathrm{Ca})$ is essential for crustaceans, due to calcium carbonate $\left(\mathrm{CaCO}_{3}\right)$ deposition in the new exoskeleton to harden it. The purpose of this work was to study short term $\mathrm{Ca}$ balance in terms of dietary $\mathrm{Ca}$ ingestion in two phylogenetically related crabs (Superfamily Grapsoidea) showing different degrees of terrestrial adaptations: Sesarma rectum Randall, 1840 and Neohelice granulata (Dana, 1851). Dietary Ca ingestion was studied using purified diets with different Ca concentrations $(0,2.2$ and $6.66 \%$ Ca), together with measurements of $\mathrm{Ca}$ excretion and $\mathrm{Ca}$ hemolymph levels. The results showed that both crabs had the same response to foods containing different levels of $\mathrm{Ca}$, with both species eating more of the high $\mathrm{Ca}$ diet. However, S. rectum consumed more per mg body mass at all Ca concentrations $\left(6 \mathrm{mg} \cdot \mathrm{g}^{-1}\right.$ for $S$. rectum against $3 \mathrm{mg} \cdot \mathrm{g}^{-1}$ for $N$. granulata). Both species excreted/egested Ca differently: $S$. rectum excreted Ca proportionally to ingestion, whereas $N$. granulata maintained constant faecal Ca output at all dietary Ca levels. Moreover, Ca hemolymph levels for crabs fed the different diets were independent of dietary Ca. In conclusion, both $S$. rectum and $N$. granulata seem to regulate the consumption of diets containing more $\mathrm{Ca}$, which suggests a fine balance for $\mathrm{Ca}$ intake.
\end{abstract}

KEYWORDS. Diet, semi-terrestrial crabs, feeding behavior, Sesarma rectum, Neohelice granulata.

RESUMO. A importância do consumo de cálcio na dieta de duas espécies de caranguejos grapsóides semi-terrestres. O cálcio (Ca) é essencial para os crustáceos porque cristais de carbonato de cálcio $\left(\mathrm{CaCO}_{3}\right)$ são depositados no novo exoesqueleto para endurecê-lo. O objetivo do presente trabalho foi estudar o balanço do $\mathrm{Ca}$ em relação à sua ingestão em dois caranguejos filogenéticamente relacionados (Superfamília Grapsoidea), que apresentam diferentes graus de terrestrialidade: Sesarma rectum Randall, 1840 e Neohelice granulata (Dana, 1851). A ingestão de Ca foi estudada através do uso de dietas purificadas com diferentes quantidades de Ca $(0,2,2$ e 6,66 \% Ca), juntamente com a excreção de Ca nas fezes e níveis de Ca na hemolinfa. Os resultados mostraram que ambos apresentam a mesma resposta em relação aos níveis de Ca na dieta, ingerindo mais da dieta com maior quantidade de Ca. Sesarma rectum, porem, consumiu mais dieta por $\mathrm{mg}$ de peso para todas as concentrações de Ca utilizadas $\left(6 \mathrm{mg} \cdot \mathrm{g}^{-1}\right.$ para $S$. rectum contra $3 \mathrm{mg} \cdot \mathrm{g}^{-1}$ para $N$. granulata). As duas espécies excretaram $\mathrm{Ca}$ de maneira diferente: $S$. rectum excretou em proporção direta à quantidade ingerida, enquanto N. granulata manteve constante a excreção de Ca independente do Ca ingerido. Níveis de Ca na hemolinfa, por outro lado, foram iguais e independentes da quantidade de Ca ingerido para os dois caranguejos. Desse modo, tanto S. rectum como N. granulata parecem discriminar e ingerir dietas com maior quantidade de $\mathrm{Ca}$, sugerindo uma regulação fina na ingestão do Ca.

PALAVRAS-CHAVE. Dieta, caranguejo semi-terrestre, comportamento alimentar, Sesarma rectum, Neohelice granulata.

Calcium $(\mathrm{Ca})$ is essential for crustaceans, because calcium carbonate crystals $(\mathrm{CaCO} 3)$ are deposited in the exoskeleton to harden it after the old exoskeleton has been shed. Critical periods for the intake of this mineral occur during molting-related events, when crustaceans shed their old exoskeleton and calcify the new one during the post-molt period. Whole body Ca uptake in these animals occurs mainly through the gills for aquatic species and transitions from intermolt (zero net flux) to premolt (net efflux) and postmolt (net influx at the rate of $2 \mathrm{mmol} / \mathrm{kg} / \mathrm{h}$; ZANOTTO \& WHEATLY, 2002). As such, crabs appear to have evolved mechanisms for calcium regulation through the gills and it is expected that regulation through dietary intake would also be important for the animals in terms of mineral regulation. Dietary intake of calcium, in particular, should be especially important for semi- and terrestrial crabs, the focus of this work, and it is already known that terrestrial crabs display different strategies to conserve $\mathrm{Ca}$ such as storage in the hemolymph and in the digestive system during premolt (GREENAWAY, 1988).

Terrestrial crabs and hermit crabs show a strong capacity to control salt and water balance, through control of drinking and excretion of salts (WоLCOTT \& WоLCOTT, 1988; TAYLOR et al., 1993; GREENAWAY, 1994). They are able to reabsorb ions from the urine through drinking after it has been voided and through recycling in the branchial chamber (Wolcott \& Wolcott, 1988; Greenaway \& Nakamura, 1991; Wolcott \& Wolcott, 1991). Calcium, for example, is regulated in the final excretory fluid after post-renal modification of the urine, so that it is found in higher or lower concentration in this fluid, depending whether the crab is drinking diluted or concentrated seawater (TAYLOR et al., 1993). They also show behavioral osmoregulation, choosing between drinking water sources of appropriate salinity and adjusting the frequency and duration of drinking (GROss, 1955). Therefore, salt control through behavioral and physiological regulation are known in crabs and $\mathrm{Ca}$, in particular, is an important ion for studies on physiological regulation of ingestion and excretion.

In spite of the great importance of nutrition, complete nutritional requirements have only been identified for a remarkably small number of living organisms. These include a variety of plants, some 
bacteria, fungi, the laboratory mouse and rat, domestic animals and some few insects of economic importance (see review by Louw, 1993). This occurs because the analysis of individual nutritional elements is an extremely tedious and labor intensive work and involves a deep understanding of the organism's general biology, together with optimum laboratory holding conditions for the organism under study. Moreover, specific work in the literature on crustacean nutrition using purified diets has been focused mainly on shrimps, due to their commercial economic importance as human food (CHEN et al., 1991; ShiAu \& LiU, 1994; ChEn \& ChANG, 1994; Shiau \& Chin, 1998; Shiau \& Hsu, 1999). Work on nutritional requirements of brachyuran crabs have been neglected (ZаNотто, 2000). Based on that, minimal knowledge of nutritional aspects of brachyuran crabs have been developed through the use of purified diets. Moreover, focus on nutritional requirements of omnivores, such as the crabs to be studied here, have the potential to form conceptual links between dietary choice by herbivores, frugivores, detritivores and predators together (Buck et al., 2003).

Therefore, the purpose of this work was to study short term calcium balance in two phylogenetically related crabs (Sesarma rectum Randall, 1840 and Neohelice granulata (Dana, 1851), Superfamily Grapsoidea) showing different degrees of terrestrial adaptations, according to the classification of crab terrestriality found in HARTNOLL (1988). The hypothesis for the present work is that the more terrestrial crab species, $S$. rectum, will regulate calcium intake and excretion more tightly than the less terrestrial species, $N$. granulata, since the former will have a greater likelihood of finding itself without an opportunity for $\mathrm{Ca}$ uptake via the gills from the surrounding water. The diets offered to the animals were formulated according to a literature review on insect diets (DADD, 1985) and a few references on crab diets (SHEEN et al., 1994; Ponat \& Adelung, 1983; SheEn \& Wu, 2002; ZANOTTO, 2000). The diets tested were tightly controlled for dietary calcium content.

\section{MATERIAL AND METHODS}

Sesarma rectum was collected from the Itaguaré River estuary near Bertioga (23 47.716' S, 46 $\left.{ }^{\circ} 03.327^{\prime} \mathrm{W}\right)$, in São Paulo State, Brazil. Neohelice granulata specimens were obtained from Laguna dos Patos, State of Rio Grande do Sul, Brazil. In the laboratory, the crabs were held in tanks containing aerated seawater at $16 \%$ (S. rectum) where they had free access to a dry surface. The animals were fed three times a week with mangrove leaves (S. rectum) and minced meat (N. granulata). The temperature was maintained at $22^{\circ}$ $\mathrm{C}$ and the photoperiod at 13:11 L/D. Neohelice granulata was also maintained at $16 \%$.

The diets offered to the crabs were composed as detailed in table I. Usually, the amount of $\mathrm{Ca}$ in the diet of $S$. rectum is around 0.4-1.0\%, amount encountered in Avicennia sp. (Verbenaceae) leaves. For N. granulata, these animals were fed minced meat before experiments started, which contains $\mathrm{Ca}$ at around $0.02 \%$. The choice of dietary Ca used here was also based on GREENAWAY \& LinTON (1995), studying a terrestrial crab that consumes leaves containing $4 \%$ of $\mathrm{Ca}$. Therefore, we used diets varying from 0 to $6.6 \%$ of $\mathrm{Ca}$.

All animals used were in the intermolt period. The animals were held without food for $48 \mathrm{~h}$ prior to experimentation. Then, the diets were offered to the animals for the next 4 days, every other day, before experiments started, to allow the animals to get used to the new purified diet (pre-treatment). After that, the animals were weighed. The experimental boxes used for feeding were inclined to separate a dry part, for the diets, and a wet part, where the animals could submerge. The dry part was separated from the wet part using a plastic square. The wet part of the box contained artificial seawater (PANTIN, 1948; Tab. II). Therefore, the diets were offered for $2 \mathrm{~h}$ in the dry part of the experimental box individually (considered day 1 ). To facilitate consumption of the dry diets, these were moistened with $0.5 \mathrm{ml}$ of distilled water. Next, the diets were offered for the next 15 days, on days $1,3,5,7,9$ and 11 , for $1 \mathrm{~h}$ again, and removed after that. Faeces, however, were collected every day and frozen for later measurement of total $\mathrm{Ca}$. Hemolymph samples were collected on the last day of the experiment, for total hemolymph Ca measurements.

The uneaten diets were dried for $48 \mathrm{~h}$ at $35^{\circ} \mathrm{C}$ and weighed to calculate amounts eaten. Faeces were ovendried at $70^{\circ} \mathrm{C}$ for $72 \mathrm{~h}$, to get dry weight and ashed at $500^{\circ} \mathrm{C}$ for $2 \mathrm{~h}$, to measure total $\mathrm{Ca}$ in a flame photometer. Haemolymph samples were also measured for total $\mathrm{Ca}$.

The data was checked for normality and homogeneity of variance using a SPSS software. Repeated measures ANOVA was used to see the effects of time in the amount of diet consumed and to compare both species and different feeding stimulants added to the diets. Hemolymph $\mathrm{Ca}$ and faecal $\mathrm{Ca}$ excretion was compared between species and diets using two-way ANOVA.

\section{RESULTS}

Sesarma rectum fed diets containing betaine as a feeding stimulant, consumed more of the diet containing $\mathrm{Ca}$ at $6.66 \%$ compared to the other diets (Fig. 1; repeated measures ANOVA, $\mathrm{P}<0.01)$. The overall consumption was around $6 \mathrm{mg} \cdot \mathrm{g}^{-1}$ for the latter diet and around

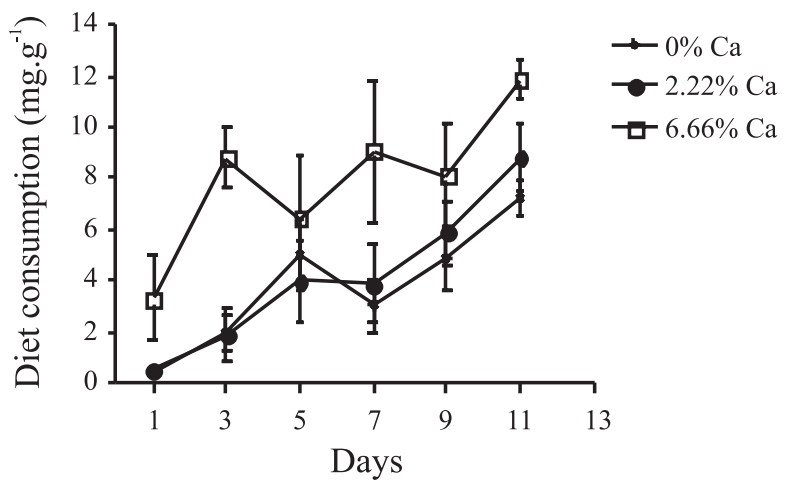

Figure 1. Mean diet consumption $\left(\mathrm{mg} \cdot \mathrm{g}^{-1}\right)$ for Sesarma rectum Randall, 1840 for every 2 days (total of 11 days), fed purified diets which contained 3 different Ca concentrations $(0 \%, 2.22 \%$ and $6.66 \%)$. There was a higher consumption for diets containing $6.66 \%$ of $\mathrm{Ca}$ compared to the other diets (repeated measures ANOVA, $\mathrm{P}<0.01 ; \mathrm{N}=10$ ). 
3-4 mg. $\mathrm{g}^{-1}$ for the other diets containing $\mathrm{Ca}$ at $0 \%$ and $2.22 \%$. There was also an effect of day (repeated measures ANOVA, $\mathrm{P}<0.01$ ) showing that the overall consumption of diet varied over 11 days for all diets.

In the case of $N$. granulata fed diets with betaine at different $\mathrm{Ca}$ concentrations, the same pattern of consumption was found compared to $S$. rectum (Fig. 1, 2). Neohelice granulata ate more of the diet containing $\mathrm{Ca}$ at $6.66 \% \mathrm{Ca}$, at around 3-6 mg.g ${ }^{-1}$ (repeated measures ANOVA, $\mathrm{P}<0.01$ ). There was also a strong effect of days, the consumption over the days showing a large variation for all diets (repeated measures ANOVA, $\mathrm{P}<0.001$ ). Again, the consumption for diets containing $\mathrm{Ca}$ at 0 and $2.22 \%$ was lower and around 2-2.5 mg.g ${ }^{-1}$ (Fig. 2). Total Ca consumption was higher for diets containing $6.66 \% \mathrm{Ca}$ for both crabs, values around $4 x$ higher compared to $S$. rectum fed diets containing $2.22 \%$ of $\mathrm{Ca}$ (Tab. III) and $2.2 \mathrm{x}$ higher $\mathrm{Ca}$ ingestion was seen for $N$. granulata compared to the same animals fed $2.22 \%$ of $\mathrm{Ca}$.

Comparing the two crabs fed diets with $\mathrm{Ca}$ at $2.22 \%$ and added betaine or cadaverine as feeding stimulants, there were differences in consumption between both feeding stimulants (Fig. 3). Sesarma rectum, however, ate more diet than $N$. granulata, at around $6-8 \mathrm{mg} \cdot \mathrm{g}^{-1}$

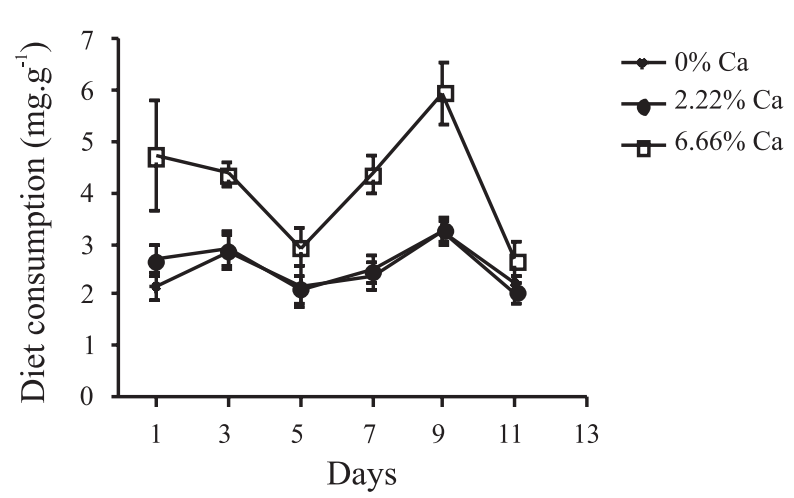

Figure 2. Mean diet consumption $\left(\mathrm{mg} \cdot \mathrm{g}^{-1}\right)$ for Neohelice granulata (Dana, 1851) for every 2 days (total of 11 days), fed purified diets which contained 3 different $\mathrm{Ca}$ concentrations $(0 \%, 2.22 \%$ and $6.66 \%)$. There was a higher consumption for diets containing $6.66 \%$ of $\mathrm{Ca}$ compared to the other diets (repeated measures ANOVA, $\mathrm{P}<0.01 ; \mathrm{N}=5$ for diet with $0 \% \mathrm{Ca} ; \mathrm{N}=6$ for the other diets).

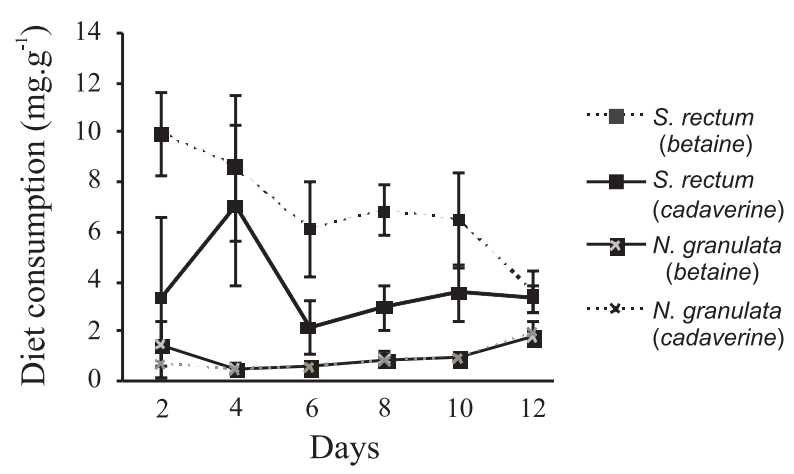

Figure 3. Total diet consumption $\left(\mathrm{mg} \cdot \mathrm{g}^{-1}\right)$, with added betaine or cadaverine, for Neohelice granulata (Dana, 1851) and Sesarma rectum Randall, 1840 fed diet containing $2.22 \% \mathrm{Ca}$. There was a significant higher consumption of diet by $S$. rectum compared to $N$. granulata for both feeding stimulants (repeated measures ANOVA, $\mathrm{P}<0.01)$. compared to 1-2 $\mathrm{mg} \cdot \mathrm{g}^{-1}$ for $N$. granulata (repeated measures ANOVA, $\mathrm{P}<0.01$ ). There was no difference in consumption for $N$. granulata in relation to the type of diet consumed, whether the diet had betaine or cadaverine (repeated measures ANOVA, P>0.05; Fig. 3), differently to what was seen for $S$. rectum, consuming more of the diet that contained betaine (repeated measures ANOVA, $\mathrm{P}<0.05$; Fig. 3).

In relation to the egestion/excretion of $\mathrm{Ca}$ in the faeces (Fig. 4), very different regulatory mechanisms were seen between the two species. Sesarma rectum excreted $\mathrm{Ca}$ proportional to the intake of $\mathrm{Ca}$ in the diets, $1.5 \mathrm{x}$ more for diet $2.22 \% \mathrm{Ca}$ compared to $0 \% \mathrm{Ca}$ and $1.5 \mathrm{x}$ more for diet $6.66 \%$ Ca compared to $2.22 \% \mathrm{Ca}$ (one-way ANOVA, $\mathrm{P}<0.05$ ). For $N$. granulata, the egestion/excretion of $\mathrm{Ca}$ was very similar on all diets, although the consumption of $\mathrm{Ca}$ between diets was different (Tab. III).

Total amounts of $\mathrm{Ca}$ in the hemolymph of the animals at the last day of the experiment are shown in figure 5. Although they were fed diets with different levels of $\mathrm{Ca}$, hemolymph $\mathrm{Ca}$ was kept constant for each crab (one-way ANOVA, $\mathrm{P}>0.05$ for both crabs), showing that there was no effect of diet in relation to $\mathrm{Ca}$ levels in the hemolymph.

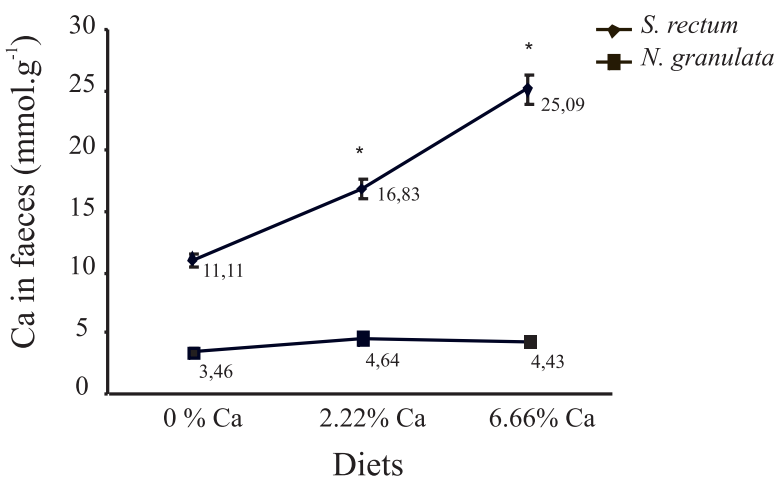

Figure 4. Mean Ca concentration in faeces of Sesarma rectum Randall, 1840 and Neohelice granulata (Dana, 1851) (mmol. $\mathrm{g}^{-1}$ ) for 3 different diets $(0 \% \mathrm{Ca}, 2.22 \% \mathrm{Ca}$ and $6.66 \% \mathrm{Ca} ; \mathrm{N}=4)$.

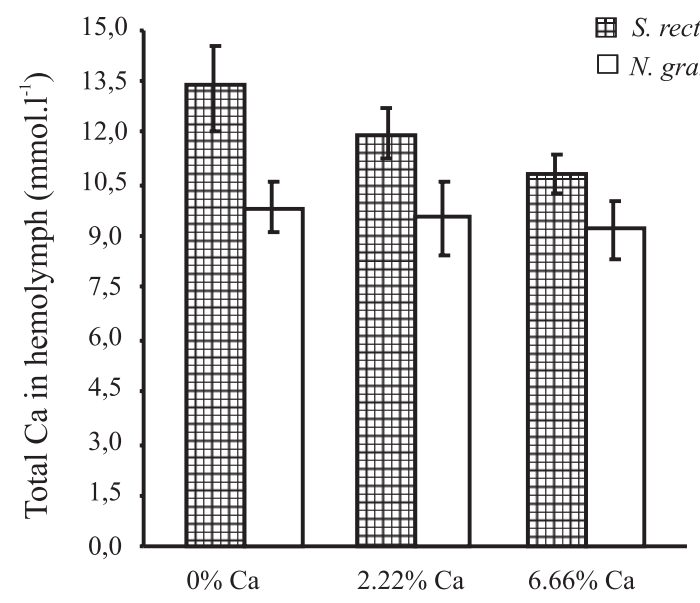

Figure 5. Mean hemolymph $\mathrm{Ca}$ concentration (mmol.1-1) in Sesarma rectum Randall, 1840 and Neohelice granulata (Dana, 1851) fed purified diets which contained 3 different $\mathrm{Ca}$ concentrations $(0 \%, 2.22 \%$ and $6.66 \%)$. There was no difference in total hemolymph $\mathrm{Ca}$ for both crabs (one-way ANOVA, P > $0.05 ; \mathrm{N}=10)$. 
Table I. Diet composition offered to the crabs Sesarma rectum Randall, 1840 and Neohelice granulata (Dana, 1851) for 15 days. Diet $\mathrm{A}, \mathrm{B}$ and $\mathrm{C}$ differed only in relation to $\mathrm{Ca}$ content (*alcium free salt mixture (ICN): $\mathrm{KPO}_{4}: 52.81 \%$; $\mathrm{NaPO}_{4}: 10.31 \%$; $\mathrm{MgSO}_{4} .7 \mathrm{H}_{2} 0: 8.19 \%$; NaCl: $23.13 \%$; iron citrate: $4.5 \%$; KI: 0.13 $\% ; \mathrm{MgSO}_{4} \cdot 1 \mathrm{H}_{2} 0: 0.74 \% ; \mathrm{ZnCl}: 0.08 \%$; $\mathrm{CuSO}_{4} .5 \mathrm{H}_{2} 0: 0.05 \%$; sodium selenite: $0.001 \%$; chromium potassium sulfate: $0.06 \%$; **AIN Vitamin Mixture 76 (ICN) - kg of mixture: thiamine hydrochloride: $600 \mathrm{mg}$; riboflavin: $600 \mathrm{mg}$; pyridoxine hydochloride: $700 \mathrm{mg}$; nicotinic acid: $3 \mathrm{~g}$; D-calcium pantothenate: $1.6 \mathrm{~g}$; folic acid: $200 \mathrm{mg}$; D-biotin: $20 \mathrm{mg}$; vitamin B12: $1 \mathrm{mg}$; vitamin A: 1.6 g (250.000 UI/g); DL-tocopherol acetate: $20 \mathrm{~g}(250 \mathrm{UI} / \mathrm{g})$; vitamin D3: $250 \mathrm{mg}$ (400.000 UI/g); vitamin K2: $5 \mathrm{mg}$; sucrose $972.9 \mathrm{~g}$ ).

\begin{tabular}{|c|c|c|c|c|c|c|}
\hline \multirow{2}{*}{$\begin{array}{l}\text { Ingredients } \\
\text { Casein }\end{array}$} & \multicolumn{2}{|c|}{$\begin{array}{c}\text { Diet A } \\
(0 \% \mathrm{Ca})\end{array}$} & \multicolumn{2}{|c|}{$\begin{array}{c}\text { Diet B } \\
(2.22 \% \mathrm{Ca})\end{array}$} & \multicolumn{2}{|c|}{$\begin{array}{c}\text { Diet C } \\
(6.66 \% \mathrm{Ca}\end{array}$} \\
\hline & 20.5 & $\mathrm{~g}$ & 20.5 & $\mathrm{~g}$ & 20.5 & $\mathrm{~g}$ \\
\hline Peptone & 5.0 & $\mathrm{~g}$ & 5.0 & $\mathrm{~g}$ & 5.0 & $\mathrm{~g}$ \\
\hline Sucrose & 5.0 & $\mathrm{~g}$ & 5.0 & $\mathrm{~g}$ & 5.0 & $\mathrm{~g}$ \\
\hline Starch & 11.0 & $\mathrm{~g}$ & 11.0 & $\mathrm{~g}$ & 11.0 & $\mathrm{~g}$ \\
\hline Salt mixture* & 3.0 & g & 3.0 & $\mathrm{~g}$ & 3.0 & g \\
\hline Vitamins** & 0.1 & $\mathrm{~g}$ & 0.1 & $\mathrm{~g}$ & 0.1 & $\mathrm{~g}$ \\
\hline Vitamin $\mathrm{C}$ & 0.2 & $\mathrm{~g}$ & 0.2 & $\mathrm{~g}$ & 0.2 & $\mathrm{~g}$ \\
\hline Betain or cadaverine & 0.8 & $\mathrm{~g}$ & 0.8 & $\mathrm{~g}$ & 0.8 & $\mathrm{~g}$ \\
\hline Corn oil & 1.9 & $\mathrm{ml}$ & 1.9 & $\mathrm{ml}$ & 1.9 & $\mathrm{ml}$ \\
\hline Cod oil & 1.9 & $\mathrm{ml}$ & 1.9 & $\mathrm{ml}$ & 1.9 & $\mathrm{ml}$ \\
\hline Cholesterol & 0.5 & g & 0.5 & $\mathrm{~g}$ & 0.5 & $\mathrm{~g}$ \\
\hline $\mathrm{CaCl}_{2}$ & 0.0 & $\mathrm{~g}$ & 1.11 & $\mathrm{~g}$ & 3.33 & g \\
\hline Total & 49.9 & $\mathrm{~g}$ & 51.01 & $\mathrm{~g}$ & 54.34 & $\mathrm{~g}$ \\
\hline
\end{tabular}

Table II. Composition of artificial brackish water at $16 \%$ (adapted from PANTIN, 1948).

\begin{tabular}{ll}
\hline Salt & $\mathrm{g} / \mathrm{L}$ \\
\hline $\mathrm{NaBr}_{2}$ (anhydrous) & 0.03 \\
$\mathrm{NaHCO}_{3}$ & 0.1 \\
$\mathrm{KCl}$ & 0.34 \\
$\mathrm{CaCl}_{2}$ (anhydrous) & 1.12 \\
$\mathrm{Na}_{2} \mathrm{SO}_{4}$ (anhydrous) & 1.8 \\
$\mathrm{MgCl}_{2} \cdot 6 \mathrm{H}_{2} \mathrm{O}$ & 4.84 \\
$\mathrm{NaCl}$ & 10.7 \\
\hline
\end{tabular}

Table III. Total Ca consumption (mg) over 13 days for Sesarma rectum Randall, 1840 and Neohelice granulata (Dana, 1851) fed 3 different diets containing betaine (mean $\pm \mathrm{SE} ; \mathrm{N}=10$ for $\mathrm{S}$. rectum and $\mathrm{N}=6$ for $N$. granulata). Asterisks denote significant differences.

\begin{tabular}{lcc}
\hline & \multicolumn{2}{c}{ Ca consumption $(\mathrm{mg})$} \\
\cline { 2 - 3 } Diet Ca & Sesarma rectum & Neohelice granulata \\
\hline $0 \%$ & 0 & 0 \\
$2.22 \%$ & $11.39 \pm 2.15$ & $12.78 \pm 6.28$ \\
$6.66 \%$ & $48.29 \pm 5.52 *$ & $28.29 \pm 1.19 *$ \\
\hline
\end{tabular}

\section{DISCUSSION}

We found here that two phylogenetically related crabs with different feeding habits and different degrees of terrestriality show different patterns of regulation of ingested $\mathrm{Ca}$. The results showed that both crabs had the same response to foods containing different levels of $\mathrm{Ca}$, with both species eating more of the high $\mathrm{Ca}$ diet. However, $S$. rectum consumed more per body mass at all $\mathrm{Ca}$ concentrations and show a higher degree of terrestriality compared to $N$. granulata. Moreover, the species excreted/egested Ca differently: $S$. rectum excreted Ca proportionally to ingestion, whereas $N$. granulata maintained constant faecal Ca output. Sesarma rectum usually feeds on a mixed diet but the diet is composed mainly of mangrove leaves (around $75 \%$, see SteINKE et al., 1993) and $N$. granulata feeds on a diet composed of fewer plant matter, showing an opportunist behavior in relation to foods encountered (KUCHARSKI \& SiLVA, 1991). This study also demonstrated for the first time the effects of known feeding stimulants, such as betaine or cadaverine (see ComAN et al., 1996) in the intake patterns of crabs, an understudied group of crustaceans in relation to non-natural food sources.

In general, animals have evolved mechanisms to balance the intake of nutrients they get from the food. These mechanisms involve nutrient balancing through behavioral means, such as food selection and regulation of amounts eaten (see WaLDBAUER \& Friedman, 1991; Simpson \& Simpson, 1990). Other means of balancing nutrient intake involves physiological regulation, in contrast to behavioral regulation, and is achieved through change in the amount of digestive enzyme produced (SABAT \& NovoA, 1998), absorptive regulation through differential absorption in the digestive system (Titus et al., 1991; Diamond, 1991; CAVIEDES-VidAL \& Karasov, 1996) and/or post-absorptive regulation, achieved mainly through differential excretion (ZаNOTTO et al., 1993, 1994).

Physiological regulation of food intake has been shown earlier in herbivorous land crabs, using natural food sources. This has involved changing food residence time in the gut and increasing assimilation efficiencies of minerals, nitrogen and dry matter content present in natural foods such as leaves (GREENAWAY \& LiNTON, 1995). Calcium assimilation from the leaves by Gecarcoidea natalis (Pocock, 1888) was 34-40\% of the Ca present in the diet, indicating that much of the Ca was lost in the faeces. In our work we saw different patterns of $\mathrm{Ca}$ egestion in two different crabs, one retaining $\mathrm{Ca}$ differently when subjected to diets with different levels of $\mathrm{Ca}(S$. rectum), and the other excreting $\mathrm{Ca}$ at quantities which were independent of the levels in the diet $(N$. granulata). The excretion/egestion was independent of $\mathrm{Ca}$ levels in the hemolymph for both crabs, levels being maintained the same independent of dietary Ca consumed. Here, the assimilation of $\mathrm{Ca}$ from purified diets was around $47 \%$ for $S$. rectum fed diet containing $2.22 \% \mathrm{Ca}$ and $78 \%$ for crabs fed diet with $6.66 \% \mathrm{Ca}$, showing an increase in $\mathrm{Ca}$ assimilation with increasing dietary levels. For isopods, for example, $\mathrm{Ca}$ assimilation is around $79-84 \%$ of total $\mathrm{Ca}$ eaten, although these crustaceans have more terrestrial features than the crabs studied here (RADU et al., 1971).

Earlier work has shown that terrestrial crabs also display behavioral regulation during food intake (Greenaway, 1993; Greenaway \& Raghaven, 1998). Two species of herbivorous land crabs, G. natalis and Discoplax hirtipes (Dana, 1852) displayed different feeding strategies when offered leaves found in their natural environment (GREENAWAY \& RAGHAVEN, 1998) and as a result $G$. natalis had a higher intake of $\mathrm{Ca}$ in the field when compared to $D$. hirtipes, through selection of yellow leaves that already contained more $\mathrm{Ca}$. Interestingly, 
another study with a salt marsh crab Armases cinereum (Bosc, 1802), found that salt added as $\mathrm{NaCl}$ to the artificial diets stimulated feeding by $A$. cinereum, in concentrations even higher than found in their natural environment (Pennings \& CAREFoOT, 1998). Overall, it seems that salts in general, as well as $\mathrm{Ca}$, are upregulated for crabs living in salt marsh environments, where $\mathrm{Ca}$ can be limiting. This has been suggested before for terrestrial crabs that live in areas far from the sea and where the water available is of reduced salinity (WоLсотт \& WoLCOTт, 1984, 1988, 1991).

Crustaceans are known to use the antennules as distant chemoreceptors (HAZlett, 1971; Steullet et al., 2002). Dactyl chemoreception is also involved in food detection (Hamilton \& CASE, 1983) and both seem to act together to increase food detection (HAZLETT, 1971). Land hermit crabs, with terrestrial features, are scavengers that also use olfaction to locate their food. They frequently chose foods that they had not experienced during the previous $24 \mathrm{~h}$. As a consequence of this behavior, land hermit crabs consume a broader diet, which may result in obtaining a more nutritionally balanced diet (THACKER, 1996). Presently, our crabs consumed more of the high Ca diet but were not given a choice of diet. Interestingly, it has been found that hermit crab is able to behaviorally choose shells in the environment (MESCE, 1982) and detect calcium through chemoreceptors in the dactyls which are sensitive to calcium (MEscE, 1993). This suggested "ion sensitivity" has also been noted in terrestrial isopod antennae which showed sensitivity to calcium solutions in the range of 10-100mM (cited in Mesce, 1993).

In rats, diets containing elevated concentration of $\mathrm{Ca}$ are regulated so that the animals absorb less $\mathrm{Ca}$ compared to a low Ca diet (FERRARIS \& DiAmOND, 1989; BronNER, 1996). However, in flies, there is no absorptive regulation of dietary $\mathrm{Ca}$ when they are fed high $\mathrm{Ca}$ diets, presenting a regulatory system different to that seen in rats (TAYLOR, 1985). In the results presented here, Ca was in one case excreted/egested according to dietary levels and in another case was retained despite of a higher intake on high $\mathrm{Ca}$ diets. This retention could have happened through re-absorption in the hindgut, before excretion through the faeces. The amount of $\mathrm{Ca}$ in the diet of $S$. rectum is around $0.4-1.0 \mathrm{~g} \%$ in Avicennia leaves found in their natural habitat. Neohelice granulata are omnivores and were fed minced meat before experiments started, which contains $\mathrm{Ca}$ at around $0.02 \mathrm{~g} \mathrm{\%} \mathrm{Ca.}$ Probably the levels of $\mathrm{Ca}$ encountered by these animals in the field could also reflect the differences in Ca retention between both crabs.

The hypothesis of increased terrestriality, using two species of crabs related phylogenetically, and an increase in $\mathrm{Ca}$ ingestion in the more terrestrial crab, $S$. rectum, was observed here. Similar response was seen for dietary copper, a heavy metal (SÁ et al., 2008). Interestingly, further exploring the subject of $\mathrm{Ca}$ intake in semi-terrestrial crabs should help discriminate strategies for $\mathrm{Ca}$ intake in a group of animals that represent a paradigm for the transition from aquatic to terrestrial habitats, representing the earlier stages of evolution to terrestriality (BURGGREN \& MCMAHON, 1988) and also help to elucidate evolutionary mechanisms between levels of terrestriality and strategies to regulate dietary Ca levels. Further work should involve the use of postmolt crabs to see how dietary $\mathrm{Ca}$ intake is regulated during this critical period of high $\mathrm{Ca}$ intake for the purpose of hardening the new exoskeleton.

Acknowledgments. This work was supported by Fundação de Amparo à Pesquisa do Estado de São Paulo (FAPESP) 98/097569 (FPZ) e FAPESP 01/10715-0 (FP). We would like to thank Steve Simpson for comments in the manuscript and Universidade Presbiteriana Mackenzie for support facilities.

\section{REFERENCES}

Bronner, F. 1996. Cytoplasmic transport of calcium and other inorganic ions. Comparative Biochemistry and Physiology 115B(3):313-317.

Buck, T. L.; Breed, G. A.; Pennings, S. C.; Chase, M. E.; Zimmer, M. \& CAREFoot, T. H. 2003. Diet choice in an omnivorous saltmarsh crab: different food types, body size, and habitat complexity. Journal of Experimental Marine Biology and Ecology 292(1):103-116.

Burggren, W. W. \& McMahon, B. R. 1988. Biology of the Land Crabs. In: Burggren, W. W. \& McMahon, B. R. eds. Biology of the land crabs: an introduction. Cambridge, Cambridge University. p.1-5.

Caviedes-Vidal, E. \& Karasov, W. H. 1996. Glucose and amino acid absorption in house sparrow intestine and its dietary modulation. American Journal of Physiology 271:R561R568.

Chen, H. Y. \& Chang, C. F. 1994. Quantification of vitamin C requirements for juvenile shrimp (Penaeus monodon) using polyphosphorylated L-ascorbic acid. Journal of Nutrition 124(10): 2033-2038.

Chen, H. Y.; Wu, F. C. \& TANG, S. Y. 1991. Thiamin requirement of juvenile shrimp (Penaeus monodon). Journal of Nutrition 121(12): 1984-1989.

Coman, G. J.; Sarac, H. Z.; Fielder, D. \& Thorne, M. 1996. Evaluation of crystalline amino acids, betaine and AMP as food attractants of the giant tiger prawn (Penaeus monodon). Comparative Biochemistry and Physiology 113A(3):247253.

DadD, R. H. 1985. Nutrition organisms. In: Kerkut, G. A. \& Gilbert, L. A. eds. Comprehensive insect physiology, biochemistry and pharmacology. Oxford, Pergamon. v.4. p. 313-390.

Diamond, J. 1991. Evolutionary design of intestinal nutrient absorption: enough but not too much. News in Physiological Sciences 6:92-96.

Ferraris, R. P. \& Diamond, J. M. 1989. Specific regulation of intestinal nutrient transporters by their dietary substrates. Annual Review of Physiology 51:125-141.

Greenaway, P. 1988. Ion and water balance. In: Burggren, W. W. \& McManon, B. R. eds. Biology of the Land Crabs. Cambridge, Cambridge University. p.211-248.

1993. Calcium and magnesium balance during molting in land crabs. Journal of Crustacean Biology 13(2):191197.

1994. Salt and water balance in field populations of the terrestrial crab Gecarcoidea natalis. Journal of Crustacean Biology 14(3):438-453.

Greenaway, P. \& Linton, S. M. 1995. Dietary assimilation and food retention time in the herbivorous terrestrial crab Gecarcoidea natalis. Physiological Zoology 68(6):10061028.

Greenaway, P. \& Nakamura, T. 1991. Nitrogenous excretion in two terrestrial crabs (Gecarcoidea natalis and Geograpsus grayi). Journal of Experimental Biology 64(3):767-786.

Greenaway, P. \& Raghaven, S. 1998. Digestive strategies in two species of leaf-eating land crabs (Brachyura: Gecarcinidae) in a rain forest. Physiological Zoology 71(1):36-44.

Gross, W. J. 1955. Aspects of osmotic and ionic regulation in crabs showing the terrestrial habit. American Naturalist 89:205-222. 
Hamilton, K. A. \& Case, J. F. 1983. Effects of abrasion and Na on dactyl-mediated chemoreception in mature kelp crabs, Pugettia producta (Randall). Journal of Experimental Biology 226(3):363-372.

Hartnoll, R. G. 1988. Growth and molting. In: Burggren, W. W. \& McMahon, B. R. eds. Biology of the Land Crabs. Cambridge, Cambridge University. p.186-210.

Hazlett, B. A. 1971. Chemical and chemotactic stimulation of feeding behavior in the hermit crab Petrochirus diogenes. Comparative Biochemistry and Physiology 39(A):665-670.

Kucharski, L. C. \& Silva, R. S. M. DA. 1991. Effect of diet composition on the carbohydrate and lipid metabolism in an estuarine crab, Chasmagnathus granulata (Dana, 1851). Comparative Biochemistry and Physiology 99(A):215-218.

Louw, G. N. 1993. Physiological Animal Ecology. Essex, Longman Scientific and Technical, England. 288p.

Mesce, K. A. 1982. Calcium-bearing objects elicit shell selection behavior in a hermit crab. Science 215(4535):993-995.

1993. Morphological and physiological identification of chelar sensory structures in the hermit-crab Pagurus hirsutiusculus (Decapoda). Journal of Crustacean Biology 13(1):95-110.

Pantin, C. F. A. 1948. Notes on microscopical techniques for zoologists. Cambridge, Cambridge University. $77 \mathrm{p}$.

Pennings, S. C. \& Carefoot, T. H. 1998. Feeding preferences of a generalist salt-marsh crab: relative importance of multiple plant traits. Ecology 79(6):1968-1979.

Ponat, A. \& Adelung, D. 1983. Studies to establish an optimal diet for Carcinus maenas. 3. Vitamin and quantitative lipid requirements. Marine Biology 74:275-279.

Radu, V.; Tomescu, N.; Racovitã, L. \& Imreh, S. 1971. Radioisotope researches concerning the feeding and the assimilation of $\mathrm{Ca}^{45}$ in terrestrial isopods. Pedobiologia 11:296-303.

SÁ, M. G.; Valenti, W. C. \& Zanotto, F. P. 2008. Dietary copper absorption and excretion in three semi-terrestrial grapsoid crabs with different levels of terrestrial adaptations. Journal of Comparative Biochemistry and Physiology C 148:112116.

Sabat, P. \& Novoa, F. 1998. Dietary flexibility and intestinal plasticity in birds: a field and laboratory study. Physiological Zoology 71(2):226-236.

Sheen, S. S.; Liu, P. C.; Chen, S. N. \& Chen, J. C. 1994. Cholesterol requirement of juvenile tiger shrimp (Penaeus monodon). Aquaculture 125(1-2):131-137.

SheEN, S. S. \& Wu, S. W. 2002. Essential fatty acid requirements of juvenile mud crab, Scylla serrata (Forskal, 1775) (Decapoda, Scyllaridae). Crustaceana 75:1387-1401.

Shiau, S. Y. \& Chin, Y. H. 1998. Dietary biotin requirement for maximum growth of juvenile grass shrimp, Penaeus monodon. Journal of Nutrition 128(12):2494-2497.

Shiau, S. Y. \& Hsu, C. W. 1999. Dietary pantothenic acid requirement of juvenile grass shrimp, Penaeus monodon. Journal of Nutrition 129(3):718-721.

Shiau, S. Y. \& LiU, J. S. 1994. Quantifying the vitamin K requirement of juvenile marine shrimp (Penaeus monodon) with menadione. Journal of Nutrition 124(2):277-282.

Simpson, C. L. \& Simpson, S. J. 1990. The role of various amino acids in the protein compensatory response of Locusta migratoria. Symposium Biologica Hungarica 39:39-46.

Steinke, T. D.; Rajh, A. \& Holland, A. J. 1993. The feedingbehavior of the red mangrove crab Sesarma meinerti De Man, 1887 (Crustacea, Decapoda, Grapsidae) and its effect on the degradation of mangrove leaf-litter. South African Journal of Marine Science 13:151-160.

Steullet, P.; Krutzfeldt, D. R.; Hamidani, G.; Flavus, T.; NGo, V. \& Derby, C. D. 2002. Dual antennular chemosensory pathways mediate odor-associative learning and odor discrimination in the Caribbean spiny lobster Panulirus argus. Journal of Experimental Biology 205(6):851-867.

TAYLOR, C. W. 1985. Calcium regulation in blowflies: absence of a role for midgut. American Journal of Physiology 249(18):R209-R213

Taylor, H. H.; Greenaway, P. \& Morris, S. 1993. Adaptations to a terrestrial existence by the robber crab Birgus latro L. VIII Osmotic and ionic regulation on freshwater and saline drinking regimens. Journal of Experimental Biology 179:93-113.

THACKER, H. L. 1996. American college of physicians: guidelines on cholesterol screening. Annals of Internal Medicine 125(12): 1008-1009.

Titus, E.; Karasov, W. H. \& Ahearn, G. A. 1991. Dietary modulation of intestinal nutrient transport in the teleost fish tilapia. American Journal of Physiology 261(30):R1568R1574.

Waldbauer, G. P. \& Friedman, S. 1991. Self-selection of optimal diets by insects. Annual Review of Entomology 36:43-63.

Wolcotт, D. L. \& Wolcotт, T. G. 1984. Food quality and cannibalism in the red land crab, Gecarcinus lateralis Physiological Zoology 57(3):318-324.

Wolcott, T. G. \& WolcotT, D. L. 1988. Availability of salts is not a limiting factor for the land crab Gecarcinus lateralis (Freminville). Journal of Experimental Marine Biology and Ecology 120:199-219.

1991. Ion conservation by reprocessing of urine in the land crab Gecarcinus lateralis (Freminville). Physiological Zoology 64(1):344-361.

Zаnотто, F. P. 2000. Nutritional requirements in Brachyura: a review. Nauplius 8(1):107-111.

Zanotto, F. P.; Raubenheimer, D. \& Simpson, S. J. 1994. Selective egestion of lysine by locusts fed nutritionally unbalanced foods. Journal of Insect Physiology 40(3):259-265.

Zanotto, F. P.; Simpson, S. J. \& Raubenheimer, D. 1993. The regulation of growth by locusts through post-ingestive compensation for variation in the levels of dietary protein and carbohydrate. Physiological Entomology 18:425-434.

Zanotto, F. P. \& Wheatly, M. G. 2002. Calcium balance in crustaceans: nutritional aspects of physiological regulation. Comparative Biochemistry and Physiology A 133(3):645-660 